\title{
Food Estate Management as Global Food Crisis Prevention Through the Implementation of the BNI Tani Card Program at Pulang Pisau
}

\author{
Abiwodo $^{1}$, Dhany Marlen ${ }^{2}$ \\ ${ }^{1}$ A Student of Strategic and Global Studies, University of Indonesia \\ ${ }^{2}$ VP Business Development PT Newport Marine Service, Indonesia \\ abiwodo@gmail.com,dhanymarlen@gmail.com
}

\begin{abstract}
Needs realization of the food estate concept partially in strengthening food security in the agricultural sector cannot be done by the government and society, but also involves corporations. One form of corporate involvement in this research is a program from BNI in the form of farmer cards. The farmer card program is expected to provide efficiency for farmers so that they can receive the distribution of government support in the right amount, the right type, the right time, the right place, the right quality and the right price. This study aims to measure the implementation of the BNI farmer card implementation to provide a pattern of relationship to the potential development of the food estate concept in Pulang Pisau. implementation of BNI farmer cards in the Pulang Pisau community through indicators of understanding and compliance (X1), behavior and culture (X2), economic conditions (X3), policy issues (X4), facilities and infrastructure (X5), and stakeholder support (X6) for Realization food estate concept. The research design was carried out in a cross-sectional manner using a quantitative approach through smart PLS. The results show the value of the six factors measured through the implementation of the BNI farmer card, which later on this value will become a basis for sustainability and policy adjustments in the realization of food estate in the region itself through government, community and corporate cooperation in realizing food security against global food crisis.
\end{abstract}

Keywords

food estate; farmers card food security, BN

\section{Introduction}

The soaring demand for food in the world demands that a country, including Indonesia through its government, can partially synergize together to prepare a strategy for food security (Aday, 2020) that is able to fight the issue of the Global Food Crisis (Pierre, 2020). The central and regional governments are jointly trying to overcome the issue of the global food crisis by boosting food production by developing food estates or food gardens. In fact, food estate is a grand design of economic development called the Master Plan for the Acceleration and Expansion of Indonesian Economic Development (MP3EI) 20112025. This food estate program was created to anticipate the food crisis as predicted by the World Food Agency (FAO) (Bhwana, 2020) making it a center for food agriculture for strategic logistics reserves for national defense (Laborde, 2020). The program will be one of the National Strategic Programs (PSN) 2020-2024 and is expected to be able to become one of the pillars supporting national food security, including contributing to economic stability, politics and national security (Issabella, 2020). The food estate itself in this study 
will be set in Central Kalimantan, which is a program that is becoming a trend by empowering transmigrants. Komarayanti et al (2018) stated that Local fruits and vegetables contribute to food security in the region through optimizing the utilization of resources of local fruits and vegetables as a provider of food.

The need for the partial realization of the food estate concept in strengthening food security in the agricultural sector cannot be done only by the central government and the community, but also by the participation of several SOEs as corporations that help realize government programs (Masudin, 2020). This research will focus on the corporate role of PT Bank Negara Indonesia Persero Tbk (BNI) as an agent of development which has an obligation and a role to succeed in the government's program in combating the Global Food Crisis (Laborde, 2020). One of the manifestations of this support is the realization of an integrated Food estate program with the BNI farmer card program. The BNI farmer card is an instrument which is a program to support the food estate concept issued by BNI as a corporation (Ashari, 2019). As a company with a great target in 2021 in national economic recovery during the Covid-19 pandemic, BNI plans a Food Security target in Indonesia which is one of the government's focuses and is one of the Nawacita programs through this farmer card program. At least more than 2.5 million farmer cards have been distributed in 2020, which aims to be efficient in the form of agricultural subsidies from the government for the community, through subsidies for fertilizers and agricultural needs (Chakim, 2019). Dianto et al (2020) In an increasingly advanced era like now it's not just money that is used as a means of payment but there are also ATM cards or debit cards and cards that are a symbol of lifestyle. The farmer card program is expected to provide efficiency for farmers to receive the right amount of government support, the right type, the right time, the right place, the right quality, and the right price. Therefore, every element in the realization and optimization of farmer cards through the government, BNI and the community must be a force and synergy that supports this vision.

Previous research described several factors that could hinder the optimization of the implementation of the farmer card in the development of food estates, including public misunderstanding (Fahmi, 2020) and government socialization (Kurniawati, 2020). In fact, the implementation of the BNI farmer card implementation in the community can be measured in six (6) factors, including 1) understanding and compliance with regulations; 2) behavioral and socio-cultural factors of the Kendal community; 3) factors of community economic conditions; 4) the issue of fertilizer availability when a new policy emerges; 5) factors of facilities and infrastructure; and 6) stakeholder support factor. These six factors can measure the implementation of the BNI farmer card program in community groups. A farmer card program in it will be interpreted as an integrated program in the unity between the government, the community and companies or corporations in participating in providing synergies on the values of the food estate concept (Fahmi, 2020). Thus, in this study, the authors explain the acceptance of the implementation of the farmer card in the community which is a part of the acceptance and success of a systematic food estate program in a well-defined program, where each of these factors can contain an intervention. which allows speeding up or even slowing down Cai, 2020) effectiveness in achieving the realization of the food estate concept in Pulang Pisau. This can be translated into a conceptual framework as follows: 


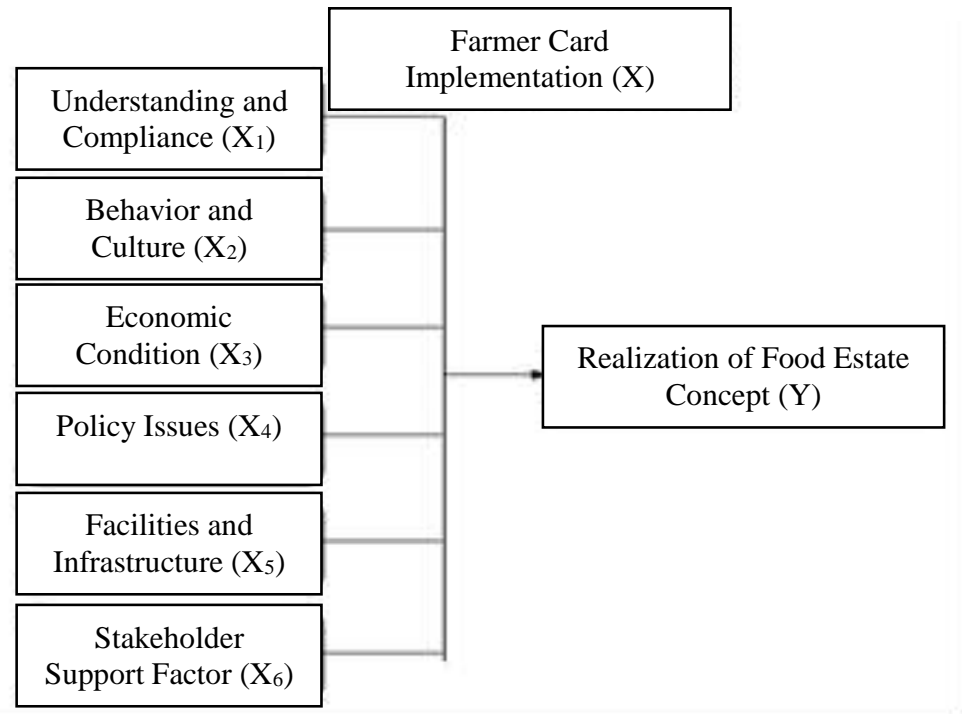

Figure 1. Conceptual Framework for Implementing Farmer Cards Measured by 6 Indicators

As for the previous description, the conceptual framework in this study will refer to the instrument to measure the implementation of the BNI farmer card (X) in the Pulang Pisau community, namely through indicators that will be translated into 6 assessment factors (X1-X6) to influence the realization of the food concept. estates (Y). Therefore, this study aims to measure the implementation of the BNI farmer card implementation to provide a relationship pattern to the potential development of the food estate concept in Pulang Pisau itself. The research hypothesis shows that there is an influence from the implementation of the BNI farmer card in the Pulang Pisau community through indicators of understanding and compliance (X1), behavior and culture (X2), economic conditions (X3), policy issues (X4), facilities and infrastructure (X5), and stakeholder support (X6) towards the realization of the food estate concept. Thus, the positive synergy of the factors measured through the implementation of the BNI farmer card is expected to have a foothold on sustainability and policy adjustments in the realization of food estate in the region itself through the cooperation of the government, communities and corporations.

\section{Research Methods}

The research design was cross-sectional using a quantitative approach. This research was conducted in Pulang Pisau Regency. The population in this study used farming communities who were willing to be contacted and then given online instruments using a form via the Google Form application (due to the Covid-19 pandemic). The time in distributing the form is limited to a period of 14 days to select the research sample. The sample is limited to farmers who have a BNI farmer card and are willing to become participants. Knowledge of the concept of food estate is also one of the screenings in determining the sample as a participant. Participants will scan questions in the form of: (1) are you registered and have a BNI farmer card?, (2) Are you willing to be a participant by answering 21 questions about farmer cards and the food estate program in Pulang Pisau Regency?. In the end the number of samples was found to be 115 participants who were willing to fill out the Gform, then the sample as participants was found to be 115 respondents or $89.1 \%$ of the total population. The number of samples was taken according to the number of samples in the PLS (Partial Least Squares) guidelines. 
To obtain the necessary data using a questionnaire. The way to measure the realization of the food estate concept, understanding and compliance, social and cultural, economic conditions, policy issues, facilities and infrastructure and stakeholder support is by using a questionnaire with a semantic differential scale, namely a scale to measure attitudes and others, but the form is not multiple choice. or checklist and arranged in a continuum line where positive answers are located on the right of the line, and negative answers are located on the left of the line, or vice versa. The data obtained by measuring the semantic differential scale is interval data and is used to measure certain attitudes or characteristics of a person. Example:

\begin{tabular}{c|c|c|c|c|c|} 
Not & $\ldots \ldots$ & $\ldots \ldots$ & $\ldots \ldots$ & $\ldots \ldots$. & $\ldots .$. \\
\cline { 2 - 6 } Always & 1 & 2 & 3 & 4 & 5 \\
\hline
\end{tabular}

Always

Respondents can give answers in the range of positive to negative answers. This depends on the perception of the respondents being assessed. Respondents who gave an assessment of 5, it means that the measurement of the realization of the food estate concept in Pulang Pisau Regency is positive and vice versa. The measurement exposure is presented as follows;

Table 1. Variables and Their Measurements

\begin{tabular}{clccc}
\hline No & \multicolumn{1}{c}{ Variable } & $\begin{array}{c}\text { Measuring } \\
\text { instrument }\end{array}$ & Measurement Results & $\begin{array}{c}\text { Measuring } \\
\text { Scale }\end{array}$ \\
\hline 1. & Realization of food estate concept & Questionnaire & Questionnaire scoring 15-60 & Interval \\
\hline 2 & Understanding and compliance & Questionnaire & Questionnaire scoring 15-60 & Interval \\
\hline 3. & Social and cultural & Questionnaire & Questionnaire scoring 15-60 & Interval \\
\hline 4. & Economic conditions & Questionnaire & Questionnaire scoring 15-60 & Interval \\
\hline 5. & Policy issues & Questionnaire & Questionnaire scoring 15-60 & Interval \\
\hline 6 & Facilities and infrastructure & Questionnaire & Questionnaire scoring 15-60 & Interval \\
\hline
\end{tabular}

The data obtained from the questionnaire results were recapitulated using the Excel program with the CSV extension and then processed using the SmartPLS program. Data analysis uses two models, descriptive analysis and Structural Equation Model (SEM), where descriptive analysis model is used to quantify the value of understanding and compliance, social and cultural factors, economic conditions, policy issues, facilities and infrastructure and stakeholder support for the realization of the food concept. estate, as well as describing the description of the research variables based on the answers to each questionnaire by giving a score for each answer. In the analysis using the average value and the percentage of the respondent's answer score. 


\section{Results and Discussion}

The research was carried out during the pandemic by observing health protocols, where information was extracted via telephone, chat and filling out forms. This becomes a limitation of research measurement. The focus of the research is the implementation of the use of farmer cards, where cards are issued by banks to farmers to be used in subsidized fertilizer redemption transactions through Electronic Data Capture machines at authorized retailers (BNI, 2020). In the implementation study, the acceptance of BNI farmer cards in the Pulang Pisau community was assessed by 6 factors, namely understanding and compliance, social and culture, economic conditions, policy issues, facilities and infrastructure and stakeholder support. These six factors will show an influence on the support for the realization of the food estate concept that has been implemented by the local government. This research will be able to become a basis for evaluating the role of corporations through the farmer card program to support the food estate concept launched by the government as a form of food security against the global food crisis. The study will include 115 participants who work in Pulang Pisau District. The assessment was filled out by respondents to assess the direct or indirect influence between understanding and compliance, economic, social and cultural conditions, policy issues, facilities and infrastructure and stakeholder support on the realization of the food estate concept in Pulang Pisau Regency. The characteristics of the respondents include age and status of migrants as part of the program.

Tabel 2. The Realization of the Food Estate Concept by Empowering the Transmigration Community

\begin{tabular}{cccc}
\hline Characteristics & & Amount & \% \\
\hline Age & $21-35$ Age & 24 & $20,8 \%$ \\
& $36-45$ Age & 61 & $53,1 \%$ \\
\cline { 2 - 4 } & $\geq 46$ Age & 30 & $26,1 \%$ \\
\hline \multirow{2}{*}{ Education } & Indigenous & 4 & $3,5 \%$ \\
\cline { 2 - 4 } & Transmigrant & 111 & $96,5 \%$ \\
\hline
\end{tabular}

The answer characteristic categories per variable from 115 participants were then processed into an assessment of the range based on variable descriptive statistics, namely:

\section{a. Understanding and Compliance Variable (X1)}

Understanding and compliance variables in this study were measured through 15 statement items with an assessment of 1-5. So the score of the questionnaire ranged from 15-75 and the actual score ranged from 48-68. 


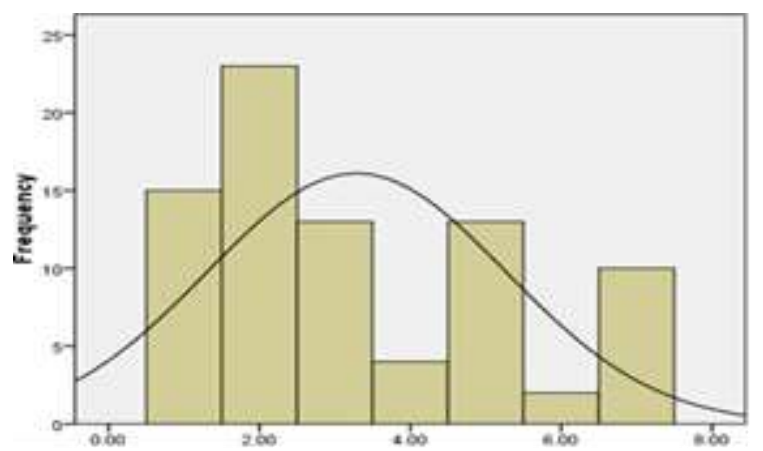

Figure 2. Histogram of Understanding and Compliance Score Frequency

The frequency distribution of respondents' scores on the understanding and compliance variables is as follows:

Table 3. Descriptive Distribution of Respondents' Answers Variable Understanding and

\begin{tabular}{rcrrcc} 
Interval & Frek & $\begin{array}{c}\text { Compliance } \\
\text { Std. Dev }\end{array}$ & Mean & Median & $\%$ \\
$48-50$ & 20 & 5.64 & 55.96 & 54 & $18.75 \%$ \\
$51-53$ & 28 & 5.64 & 55.96 & 54 & $28.75 \%$ \\
$54-56$ & 18 & 5.64 & 55.96 & 54 & $16.25 \%$ \\
$57-59$ & 9 & 5.64 & 55.96 & 54 & $5.00 \%$ \\
$60-62$ & 18 & 5.64 & 55.96 & 54 & $16.25 \%$ \\
$63-65$ & 7 & 5.64 & 55.96 & 54 & $2.50 \%$ \\
$\underline{66-68}$ & $\underline{15}$ & $\underline{5.64}$ & $\underline{55.96}$ & $\underline{54}$ & $\underline{12.50 \%}$ \\
\hline
\end{tabular}

Based on table 2, it shows that the average value is $>0.5$. Then the composite reliability value> 0.7 . So it can be concluded that the indicators in the study are able to measure well.

\section{b. Social and Cultural Variables (X2)}

Social and cultural variables in this study were measured through 15 statement items with an assessment of 1-5. So the score of the questionnaire ranged from 15-75 and the actual score ranged from 23-43.

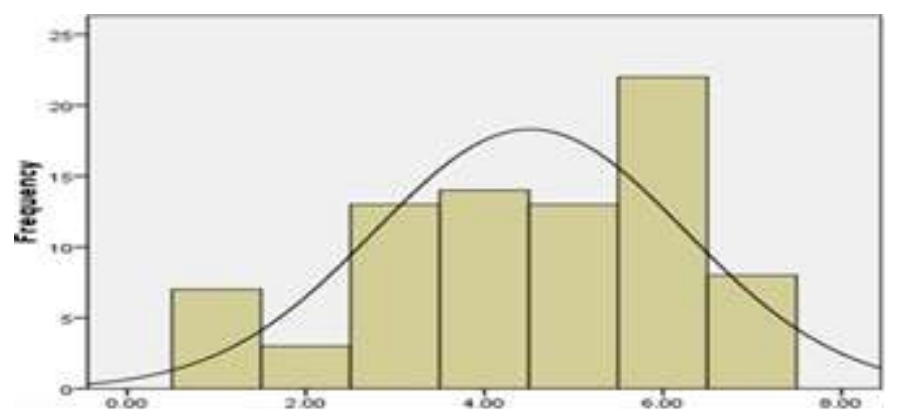

Figure 3. Histogram of Social and Cultural Score Frequency

The frequency distribution of respondents' answers to social and cultural variables is as follows: 
Table 4. Descriptive Distribution of Respondents' Answers for Social and Cultural Variables

\begin{tabular}{rllrrl}
\hline Interval & \multicolumn{6}{c}{ Frek Std. DevMean } & Median & $\%$ \\
$23-25$ & 12 & 5.30 & 34.71 & 35 & $8.75 \%$ \\
$26-28$ & 8 & 5.30 & 34.71 & 35 & $3.75 \%$ \\
$29-31$ & 18 & 5.30 & 34.71 & 35 & $16.25 \%$ \\
$32-34$ & 19 & 5.30 & 34.71 & 35 & $17.50 \%$ \\
$35-37$ & 18 & 5.30 & 34.71 & 35 & $16.25 \%$ \\
$38-40$ & 27 & 5.30 & 34.71 & 35 & $27.50 \%$ \\
$41-43$ & 13 & 5.30 & 34.71 & 35 & $10.00 \%$ \\
\hline
\end{tabular}

Based on table 4, it shows that reward has a very weak effect on student satisfaction, then satisfaction has a moderate effect on student loyalty

\section{c. Variable Economic Condition (X3)}

Variable Economic conditions in this study were measured through 15 items with an assessment of 1-5. So the score of the questionnaire ranged from 15-75 and the actual score ranged from $48-68$.

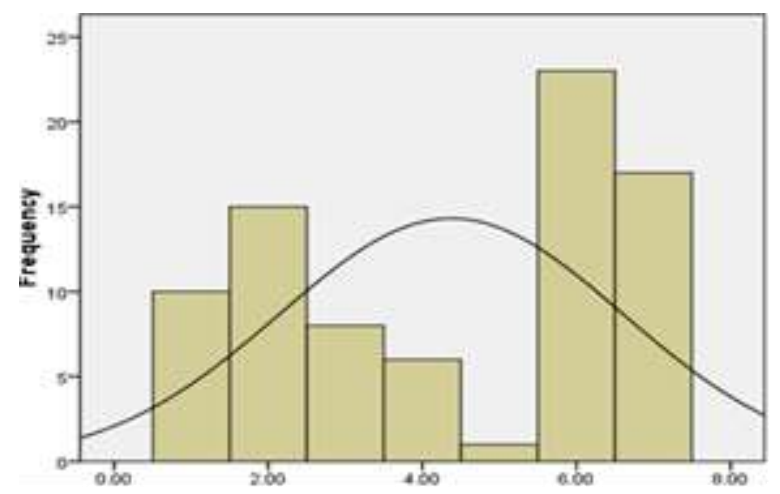

Figure 4. Histogram of Economic Condition Score Frequency

The frequency distribution of respondents' answers to the variable Economic conditions is as follows:

Table 5. The Frequency Distribution of Respondents' Answers to the Variable Economic

\begin{tabular}{rllllr}
\multicolumn{6}{c}{ Conditions } \\
\hline Interval & Frek Std. Dev Mean & Median & $\%$ \\
$48-50$ & 15 & 6.71 & 59.14 & 61.5 & $12.50 \%$ \\
$51-53$ & 20 & 6.71 & 59.14 & 61.5 & $18.75 \%$ \\
$54-56$ & 13 & 6.71 & 59.14 & 61.5 & $10.00 \%$ \\
$57-59$ & 11 & 6.71 & 59.14 & 61.5 & $7.50 \%$ \\
$60-62$ & 6 & 6.71 & 59.14 & 61.5 & $1.25 \%$ \\
$63-65$ & 28 & 6.71 & 59.14 & 61.5 & $28.75 \%$ \\
$66-68$ & 22 & 6.71 & 59.14 & 61.5 & $21.25 \%$ \\
\hline
\end{tabular}

\section{d. Policy Issue Variable (X4)}

Variable Policy issues in this study were measured through 15 statement items with an assessment of 1-5. So the score of the questionnaire ranged from 15-75 and the actual score ranged from 23-43. 


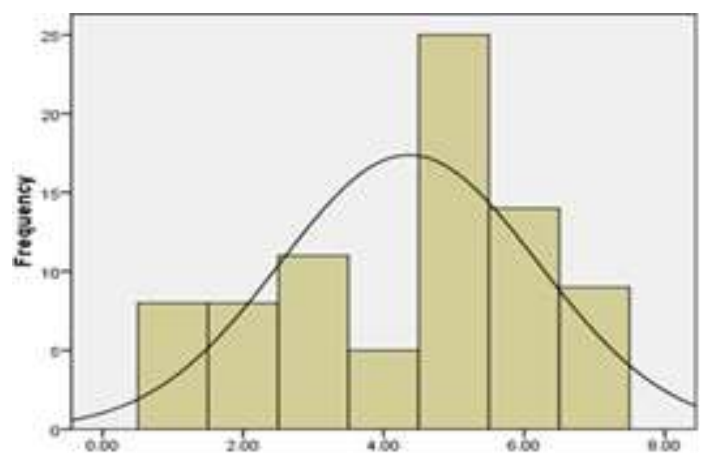

Figure 5. Histogram of Policy Issues Score Frequency

The frequency distribution of respondents' scores on the policy issue variable is as follows:

Table 6. Descriptive Distribution of Respondents' Answers Variable Policy Issues

\begin{tabular}{|c|c|c|c|c|c|}
\hline Interval & Fre & Std. Dev & Mean & Median & $\%$ \\
\hline $23-25$ & 8 & 5.58 & 34.24 & 37 & $10.00 \%$ \\
\hline $26-28$ & 8 & 5.58 & 34.24 & 37 & $10.00 \%$ \\
\hline $29-31$ & 11 & 5.58 & 34.24 & 37 & $13.75 \%$ \\
\hline $32-34$ & 5 & 5.58 & 34.24 & 37 & $6.25 \%$ \\
\hline $35-37$ & 25 & 5.58 & 34.24 & 37 & $31.25 \%$ \\
\hline $38-40$ & 14 & 5.58 & 34.24 & 37 & $17.50 \%$ \\
\hline $41-43$ & 9 & 5.58 & 34.24 & 37 & $11.25 \%$ \\
\hline
\end{tabular}

\section{e. Variable Facilities and Infrastructure (X5)}

The variables of facilities and infrastructure in this study were measured through 15 statement items with an assessment of 1-5. So the score of the questionnaire ranges from 15-75 and the actual score ranges from 40-61

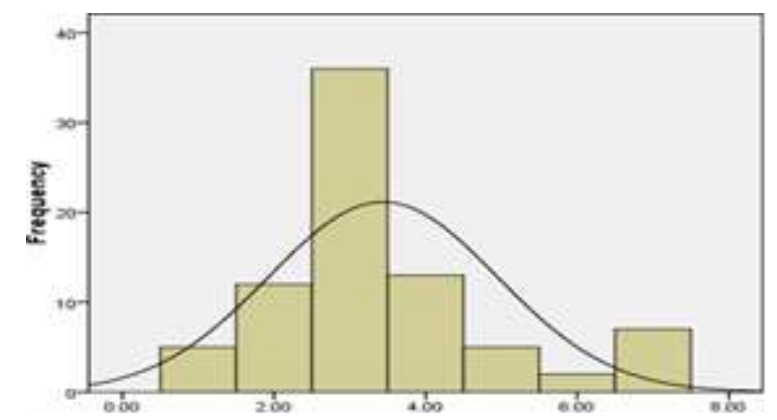

Figure 6. Histogram of the Score Frequency of Facilities and infrastructure

The frequency distribution of respondents' answers to the variables of facilities and infrastructure is as follows:

Table 7. Descriptive Distribution of Respondents' Answers for Facilities and Infrastructure

\begin{tabular}{|c|c|c|c|c|c|}
\multicolumn{7}{c|}{ Variables } \\
\hline Interval & Frek Std. Dev & Mean & Median & $\%$ \\
\hline $40-43$ & 10 & 4.86 & 49.13 & 48 & $6.25 \%$ \\
\hline $44-46$ & 17 & 4.86 & 49.13 & 48 & $15.00 \%$ \\
\hline $47-49$ & 41 & 4.86 & 49.13 & 48 & $45.00 \%$ \\
\hline $50-52$ & 18 & 4.86 & 49.13 & 48 & $16.25 \%$ \\
\hline $53-55$ & 10 & 4.86 & 49.13 & 48 & $6.25 \%$ \\
\hline $56-58$ & 7 & 4.86 & 49.13 & 48 & $2.50 \%$ \\
\hline $59-61$ & 12 & 4.86 & 49.13 & 48 & $8.75 \%$ \\
\hline
\end{tabular}




\section{f. Stakeholder Support Variable (X6)}

Stakeholder support variables in this study were measured through 15 statement items with an assessment of 1-5. So the score of the questionnaire ranged from 15-75 and the actual score ranged from 23-43.

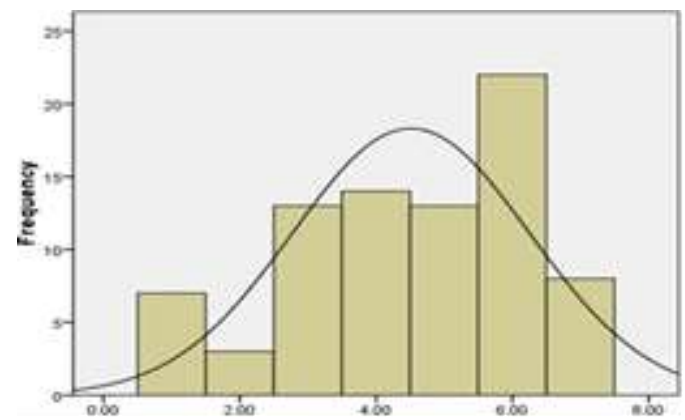

Figure 7. Histogram of Stakeholder Support Score Frequency

The frequency distribution of respondents' answers to the Stakeholder Support variable is as follows:

Table 8. Descriptive Distribution of Respondents' Answers Variable Stakeholder Support

\begin{tabular}{|c|c|c|c|c|c|}
\hline Interval & Frek & Std. Dev & Mean & Median & \% \\
\hline $23-25$ & 12 & 5.30 & 34.71 & 35 & $8.75 \%$ \\
\hline $26-28$ & 8 & 5.30 & 34.71 & 35 & $3.75 \%$ \\
\hline $29-31$ & 18 & 5.30 & 34.71 & 35 & $16.25 \%$ \\
\hline $32-34$ & 19 & 5.30 & 34.71 & 35 & $17.50 \%$ \\
\hline $35-37$ & 18 & 5.30 & 34.71 & 35 & $16.25 \%$ \\
\hline $38-40$ & 27 & 5.30 & 34.71 & 35 & $27.50 \%$ \\
\hline $41-43$ & 13 & 5.30 & 34.71 & 35 & $10.00 \%$ \\
\hline
\end{tabular}

g. Variable Realization of Food Estate Concept (Y)

Variables Realization of the concept of food estate in this study was measured through 15 statement items with an assessment of 1-5. So the score of the questionnaire ranged from 15-75 and the actual score ranged from 46-67.

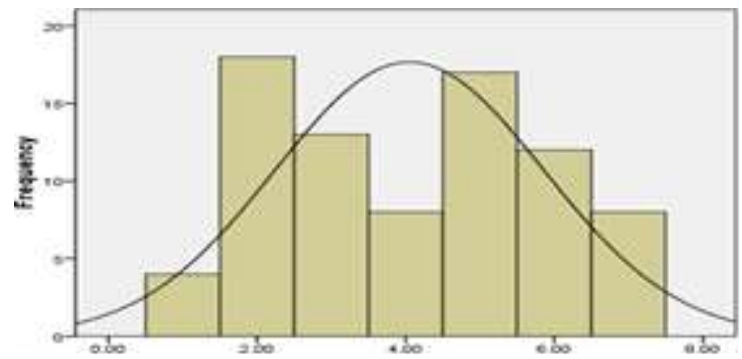

Figure 8. Histogram of the Score Frequency Realization of the Food Estate Concept

The frequency distribution of respondents' answers to the variable Realization of the food estate concept is as follows: 
Table 9. Descriptive Distribution of Respondents' Answers Variable Realization of the Concept of Food Estate

\begin{tabular}{|c|c|c|c|c|r|}
\hline Interval & Frek & Std. Dev & Mean & Median & $\%$ \\
\hline $46-48$ & 9 & 5.70 & 56.44 & 57 & $5.00 \%$ \\
\hline $49-51$ & 23 & 5.70 & 56.44 & 57 & $22.50 \%$ \\
\hline $52-54$ & 18 & 5.70 & 56.44 & 57 & $16.25 \%$ \\
\hline $55-57$ & 13 & 5.70 & 56.44 & 57 & $10.00 \%$ \\
\hline $58-60$ & 22 & 5.70 & 56.44 & 57 & $21.25 \%$ \\
\hline $61-63$ & 16 & 5.70 & 56.44 & 57 & $13.75 \%$ \\
\hline $64-67$ & 14 & 5.70 & 56.44 & 57 & $11.25 \%$ \\
\hline
\end{tabular}

The results of the Chi Square test on the variables of Realization of the food estate concept (Y), Understanding and compliance (X1), Social and culture (X2), Economic conditions (X3), Policy issues (X4), Facilities and infrastructure (X5), Stakeholder support (X6) with a significance level of $5 \%$, all are greater than 0.05 . This shows that all these variables have no relationship with the characteristics of the respondents. Indicator validity can be measured by evaluating the results of cross loading for all variables shown as follows:

Table 10. Test the Validity of the Measurement Indicator of Variables by Evaluating the Cross Loading Value (Discriminant Validity)

\begin{tabular}{|c|c|c|c|c|c|c|c|c|}
\hline \multirow[t]{2}{*}{ Validity and Reliability } & \multirow{2}{*}{ Indicator } & \multicolumn{7}{|c|}{ Varabel Laten } \\
\hline & & $X_{1}$ & $\mathbf{X}_{2}$ & $\mathbf{X}_{3}$ & $X_{4}$ & $X_{5}$ & $X_{6}$ & $\mathbf{Y}$ \\
\hline \multirow{32}{*}{$\begin{array}{l}\text { Cross Loading } \\
\text { (Discriminant } \\
\text { Validity) }\end{array}$} & $\left(\mathrm{X}_{1-1}\right)$ & 0.90 & 0.30 & 0.54 & 0.50 & 0.29 & 0.58 & 0.51 \\
\hline & & 7 & 3 & 1 & 5 & 6 & 2 & 7 \\
\hline & $\left(\mathrm{X}_{1-2}\right)$ & 0.95 & 0.29 & 0.50 & 0.69 & 0.46 & 0.42 & 0.52 \\
\hline & & 8 & 9 & 4 & 9 & 1 & 6 & 7 \\
\hline & $\left(X_{1-3}\right)$ & 0.90 & 0.20 & 0.39 & 0.63 & 0.33 & 0.29 & 0.36 \\
\hline & & 8 & 3 & 6 & 4 & 4 & 2 & 0 \\
\hline & $\left(\mathrm{X}_{2-1}\right)$ & 0.58 & 0.41 & 0.94 & 0.63 & 0.48 & 0.50 & 0.69 \\
\hline & & 7 & 0 & 8 & 0 & 8 & 7 & 0 \\
\hline & $\left(\mathrm{X}_{2-2}\right)$ & 0.40 & 0.39 & 0.94 & 0.46 & 0.48 & 0.45 & 0.74 \\
\hline & & 4 & 7 & 4 & 1 & 3 & 6 & 6 \\
\hline & $\left(\mathrm{X}_{2-3}\right)$ & 0.64 & 0.14 & 0.46 & 0.90 & 0.48 & 0.13 & 0.47 \\
\hline & & 6 & 5 & 2 & 9 & 9 & 8 & 3 \\
\hline & $\left(\mathrm{X}_{3-1}\right)$ & 0.66 & 0.25 & 0.52 & 0.90 & 0.50 & 0.24 & 0.56 \\
\hline & & 0 & 4 & 2 & 3 & 8 & 5 & 6 \\
\hline & $\left(\mathrm{X}_{3-2}\right)$ & 0.63 & 0.19 & 0.54 & 0.83 & 0.55 & 0.30 & 0.70 \\
\hline & & 8 & 6 & 8 & 3 & 2 & 2 & 1 \\
\hline & $\left(\mathrm{X}_{3-3}\right)$ & 0.55 & 0.26 & 0.56 & 0.90 & 0.54 & 0.20 & 0.52 \\
\hline & & 1 & 4 & 3 & 8 & 2 & 9 & 6 \\
\hline & $\left(\mathrm{X}_{4-1}\right)$ & 0.12 & 0.25 & 0.40 & 0.37 & 0.79 & 0.11 & 0.48 \\
\hline & & 1 & 1 & 3 & 6 & 1 & 0 & 5 \\
\hline & $\left(\mathrm{X}_{4-2}\right)$ & 0.31 & 0.30 & 0.43 & 0.53 & 0.92 & 0.12 & 0.49 \\
\hline & & 5 & 1 & 8 & 6 & 2 & 6 & 5 \\
\hline & $\left(\mathrm{X}_{4-3}\right)$ & 0.41 & 0.36 & 0.57 & 0.54 & 0.86 & 0.14 & 0.56 \\
\hline & & 8 & 4 & 6 & 8 & 1 & 9 & 8 \\
\hline & $\left(\mathrm{X}_{5-1}\right)$ & 0.38 & 0.45 & 0.37 & 0.13 & 0.19 & 0.87 & 0.35 \\
\hline & & 5 & 2 & 8 & 4 & 8 & 2 & 8 \\
\hline & $\left(\mathrm{X}_{5-2}\right)$ & 0.31 & 0.41 & 0.36 & 0.17 & 0.25 & 0.90 & 0.35 \\
\hline & & 9 & 3 & 2 & 2 & 8 & 7 & 5 \\
\hline & $\left(\mathrm{X}_{5-3}\right)$ & 0.51 & 0.39 & 0.57 & 0.29 & 0.21 & 0.88 & 0.51 \\
\hline & & 8 & 7 & 7 & 4 & 1 & 4 & 9 \\
\hline & Realization of & 0.51 & 0.34 & 0.70 & 0.64 & 0.55 & 0.36 & 1 \\
\hline & estate & 3 & 1 & 6 & 6 & 9 & 7 & \\
\hline
\end{tabular}


An indicator is declared valid if it has the highest loading factor for the intended construct compared to the loading factor for other constructs. The table above shows that the loading factor value for $(\mathrm{X} 1-1)-(\mathrm{X} 1-3)$ is the highest for the understanding and compliance variable compared to other variables, so that the understanding and compliance variable is able to predict the factor loading value (X1-1) to (X1-3). ) is higher than the other variables.

Table 11. Test the Validity of Measurement Indicators of Variables by Evaluating the Outer Loading Value (Convergent Validity)

\begin{tabular}{|c|c|c|c|}
\hline Validity & Influence & $\begin{array}{l}\text { Test } \\
\text { Results }\end{array}$ & $\begin{array}{c}\text { Test Criteria } \\
>0,5\end{array}$ \\
\hline \multirow{13}{*}{ Outer Loading (Convergent Validity) } & $\left(X_{1-1}\right)$ & 0,909 & Valid \\
\hline & $\left(X_{1-2}\right)$ & 0,916 & Valid \\
\hline & $\left(X_{1-3}\right)$ & 0,896 & Valid \\
\hline & $\left(X_{2-1}\right)$ & 0,862 & Valid \\
\hline & $\left(X_{2-2}\right)$ & 0,958 & Valid \\
\hline & $\left(\mathrm{X}_{2-3}\right)$ & 0,908 & Valid \\
\hline & $\left(X_{3-1}\right)$ & 0,952 & Valid \\
\hline & $\left(X_{3-2}\right)$ & 0,972 & Valid \\
\hline & $\left(\mathrm{X}_{3-3}\right)$ & 0,948 & Valid \\
\hline & $\left(\mathrm{X}_{4-1}\right)$ & 0,944 & Valid \\
\hline & $\left(\mathrm{X}_{4-2}\right)$ & 0,839 & Valid \\
\hline & $\left(\mathrm{X}_{4-3}\right)$ & 0,838 & Valid \\
\hline & $\left(X_{5-1}\right)$ & 0,858 & Valid \\
\hline
\end{tabular}

The results of the analysis of data processing show that the construct used to form a research model, in the confirmatory factor analysis process, has met the criteria of goodness of fit that have been determined. The probability value in this analysis shows a value above the significance limit of 0.05 . From the results of data processing above, it is also seen that each indicator or dimension forming the latent variable shows good results, namely with a high loading factor value where each indicator is greater than 0.5 . With these results, it can be said that the indicators forming the latent variables of the construct of understanding and compliance, economic conditions, policy issues, facilities and infrastructure, stakeholder support and the realization of the food estate concept have shown good results. Another way to test disciminant validity is through the Square root of variance extracted (AVE) value. The expected value is above 0.50. Below is the AVE table:

Table 12. Variable Validity Test By Evaluating the Value of AVE (Average Variance Extracted)

\begin{tabular}{|l|c|c|}
\hline \multicolumn{1}{|c|}{ Variable } & AVE & Kriteria Uji $>\mathbf{0 . 5}$ \\
\hline Understanding and compliance & 0.782 & Valid \\
\hline Economic conditions & 0.828 & Valid \\
\hline social and cultural & 0.895 & Valid \\
\hline Policy issues & 0.762 & Valid \\
\hline Facilities and infrastructure & 0.658 & Valid \\
\hline Stakeholder Support & 0.813 & Valid \\
\hline Realization of Food Estate Concept & 0.926 & Valid \\
\hline
\end{tabular}


From the table above, it can be seen that all variables are declared valid because they provide an AVE value above 0.5. So it can be concluded that the evaluation of the measurement model has a good or valid discriminant validity. Another method to assess discriminant validity is to compare the value of the Square root of variance variance extracted (AVE) of each construct with the correlation between the construct and other constructs in the model, so it is said to have a good discriminant validity value.

After being tested for validity and declared that the variables and indicators have been valid, the reliability test is carried out. The reliability test is carried out by looking at the composite reliability value from the indicator block that measures the composite reliability result construct which will show a satisfactory value if it is above 0.70 . The results of the evaluation of the reliability of the outer model can be seen in the table by evaluating the value of Cronbach's Alpha and composite reliability. Here are the values:

Table 13. Variable Reliability Test by Evaluating Values in the Outer Model

\begin{tabular}{llcl|}
\hline Validitas & \multicolumn{2}{l}{ Test results } & \multicolumn{1}{c|}{$\begin{array}{c}\text { Test } \\
\text { Criteria }\end{array}$} \\
\cline { 2 - 4 } & Influence & Loading & $>0,70$ \\
\hline Cronbach's Alpha & Understanding and compliance & 0,922 & Reliabel \\
\cline { 2 - 4 } & Economic conditions & 0,883 & Reliabel \\
\cline { 2 - 4 } & Social and cultural & 0,948 & Reliabel \\
\cline { 2 - 4 } & Policy issues & 0,895 & Reliabel \\
\cline { 2 - 4 } & Facilities and infrastructure & 0,888 & Reliabel \\
\cline { 2 - 4 } & Stakeholder Support & 0,860 & Reliabel \\
\cline { 2 - 4 } CompositeReliability & Realization of Food Estate Concept & 0,939 & Reliabel \\
\cline { 2 - 4 } & Understanding and compliance & 0,962 & Reliabel \\
\cline { 2 - 4 } & Economic conditions & 0,945 & Reliabel \\
\cline { 2 - 4 } & Social and cultural & 0,957 & Reliabel \\
\cline { 2 - 4 } & Policy issues & 0,920 & Reliabel \\
\cline { 2 - 4 } & Facilities and infrastructure & 0,929 & Reliabel \\
\cline { 2 - 4 } & Stakeholder Support & 0,956 & Reliabel \\
\cline { 2 - 4 } & Realization of Food Estate Concept & 0,956 & \\
& & & \\
\hline
\end{tabular}

Based on the table above, it shows that all variables are declared reliable because the Cronbach's Alpha and Composite reliability values are above 0.70 so it can be said that the construct has good reliability. Furthermore, the Inner Model test is carried out, testing the structural model is done by looking at the R-Square which is the Goodness-fit test model. The following is the result of measuring the R-Square value, which is also the value of the goodnees-fit model.

Table 14. Evaluation of R Square Model Value

\begin{tabular}{cccc}
\hline Significance Test & Indicator & T-statistic & Reflection $>$ 1.96 \\
\cline { 2 - 4 }$(\mathrm{X} 1-1)$ & 5.426 & Significant \\
\cline { 2 - 4 }$(\mathrm{X} 1-2)$ & 1.835 & Significant \\
\hline$(\mathrm{X} 1-3)$ & 8.903 & Significant \\
\hline$(\mathrm{X} 2-1)$ & 0.356 & Significant \\
\hline$(\mathrm{X} 2-2)$ & 8.014 & Significant \\
\hline$(\mathrm{X} 2-3)$ & 2.544 & Significant \\
\hline$(\mathrm{X} 3-1)$ & 5.651 & Significant \\
\hline$(\mathrm{X} 3-2)$ & 1.933 & Significant \\
\hline$(\mathrm{X} 3-3)$ & 2.318 & Significant \\
\hline$(\mathrm{X} 4-1)$ & 1.899 & Significant \\
\hline$(\mathrm{X} 4-2)$ & 0.367 & Significant \\
\hline
\end{tabular}




\begin{tabular}{lll}
\hline$(\mathrm{X} 4-3)$ & 7.923 & Significant \\
\hline$(\mathrm{X} 5-1)$ & 4.255 & Significant \\
\hline$(\mathrm{X} 5-2)$ & 5.212 & Significant \\
\hline$(\mathrm{X} 5-3)$ & 3.982 & Significant \\
\hline$(\mathrm{X} 6-1)$ & 5,691 & Significant \\
\hline$(\mathrm{X} 6-2)$ & 7,221 & Significant \\
\hline$(\mathrm{X} 6-3)$ & 8,142 & Significant \\
\hline
\end{tabular}

Based on the table above, it can be seen that the value of $r$ square is most dominant when the components of economic, social and cultural conditions, policy issues, facilities and infrastructure and stakeholder support affect the subject well being. The results of the significant evaluation of the inner model are arranged in the SmartPLS output below by evaluating the reflection of the $\mathrm{T}$ statistic value of the indicator on the variable.

Table 15. Evaluation of the Reflection of $T$ Statistical Values on Indicators of Each Variable

\begin{tabular}{cccc}
\hline Significance Test & Indicator & T-statistic & Reflection $>$ 1.96 \\
\hline & $(\mathrm{X} 1-1)$ & 5.426 & Significant \\
\hline$(\mathrm{X} 1-2)$ & 1.835 & Significant \\
\hline$(\mathrm{X} 1-3)$ & 8.903 & Significant \\
\hline$(\mathrm{X} 2-1)$ & 0.356 & Significant \\
\hline$(\mathrm{X} 2-2)$ & 8.014 & Significant \\
\hline$(\mathrm{X} 2-3)$ & 2.544 & Significant \\
\hline$(\mathrm{X} 3-1)$ & 5.651 & Significant \\
\hline$(\mathrm{X} 3-2)$ & 1.933 & Significant \\
\hline$(\mathrm{X} 3-3)$ & 2.318 & Significant \\
\hline$(\mathrm{X} 4-1)$ & 1.899 & Significant \\
\hline$(\mathrm{X} 4-2)$ & 0.367 & Significant \\
\hline$(\mathrm{X} 4-3)$ & 7.923 & Significant \\
\hline$(\mathrm{X} 5-1)$ & 4.255 & Significant \\
\hline$(\mathrm{X} 5-2)$ & 5.212 & Significant \\
\hline$(\mathrm{X} 5-3)$ & 3.982 & Significant \\
\hline$(\mathrm{X} 6-1)$ & 5,691 & Significant \\
\hline$(\mathrm{X} 6-2)$ & 7,221 & Significant \\
\hline$(\mathrm{X} 6-3)$ & 8,142 & Significant \\
\hline
\end{tabular}

The table above states that the statistical $\mathrm{T}$ value reflected on the variable is mostly > 1.96, thus indicating the indicator block has a positive and significant effect on reflecting the variable. The results of this study found several significant findings to describe the relationship between variables, namely:

The findings of this study are:

1. There is a direct and magnitude effect between understanding and compliance, on the realization of the food estate concept of $27.34 \%$, an indirect effect of $0.51 \%$ and the $\mathrm{T}$ statistic value of 5.426 and significant at $5 \%$ alpha.

2. There is a direct and magnitude effect between economic conditions on the realization of the food estate concept of $9.07 \%$, an indirect effect of $0.01 \%$ and the T statistic value of 0.356 and significant at $5 \%$ alpha

3. There is a direct influence and magnitude between social and culture on the realization of the food estate concept of 7.21 and the T statistic value of 5.651 and significant at $5 \%$ alpha.

4. There is a direct and magnitude influence between policy issues on the realization of the food estate concept of 40.4 and the T statistic value of 1.899 and significant at $5 \%$ alpha 
5. There is a direct influence and magnitude between facilities and infrastructure on the realization of the food estate concept of 15.9 and the $\mathrm{T}$ statistic value of 4.255 and significant at $5 \%$ alpha.

6. There is a direct and magnitude influence between stakeholder support, on the realization of the food estate concept of 26.4 and the $\mathrm{T}$ statistic value of 5.691 and significant at $5 \%$ alpha.

After analyzing the data, then hypothesis testing is carried out on these variables, where this testing method is carried out by bootstrapping. The statistical test used is the $t$ test.

Table 16. Path Coefficients Measurement Results and their T Statistics Relationships between Variables in the Structural Model

\begin{tabular}{|c|c|c|c|c|}
\hline Relationship Between Variables & $\begin{array}{c}\text { Original } \\
\text { Sample } \\
\text { (Rho) }\end{array}$ & $\begin{array}{l}\text { Nilai T } \\
(>1,96)\end{array}$ & Ho & Conclusion \\
\hline $\begin{array}{l}\text { Understanding and compliance > } \\
\text { Realization of the food estate concept }\end{array}$ & 0.623 & 5.426 & Rejected & $\begin{array}{l}\text { There is a } \\
\text { positive and } \\
\text { significant } \\
\text { influence }\end{array}$ \\
\hline $\begin{array}{l}\text { Economic conditions > } \\
\text { Realization of food estate concept }\end{array}$ & 0.741 & 0.356 & Rejected & $\begin{array}{l}\text { There is a } \\
\text { positive and } \\
\text { significant } \\
\text { influence }\end{array}$ \\
\hline $\begin{array}{l}\text { Social and cultural > Concept realization } \\
\text { food estate }\end{array}$ & 0.225 & 5.651 & Rejected & $\begin{array}{l}\text { There is a } \\
\text { positive and } \\
\text { significant } \\
\text { influence }\end{array}$ \\
\hline $\begin{array}{l}\text { Isu kebijakan > Realisasi konsep food } \\
\text { estate }\end{array}$ & 0.333 & 1.899 & Rejected & $\begin{array}{l}\text { There is a } \\
\text { positive and } \\
\text { significant } \\
\text { influence }\end{array}$ \\
\hline $\begin{array}{l}\text { Facilities and infrastructure > } \\
\text { Realization of the food estate } \\
\text { concept }\end{array}$ & 0.423 & 4.255 & Rejected & $\begin{array}{l}\text { There is a } \\
\text { positive and } \\
\text { significant } \\
\text { influence }\end{array}$ \\
\hline $\begin{array}{l}\text { Stakeholder support > Realization } \\
\text { of food estate concept }\end{array}$ & 0.324 & 5,691 & Rejected & $\begin{array}{l}\text { There is a } \\
\text { positive and } \\
\text { significant } \\
\text { influence }\end{array}$ \\
\hline
\end{tabular}

Based on the table above, it can be seen that all variables have a t-statistic value greater than $1.96 \%$ and the variables Understanding and compliance, Social and culture and Stakeholder support for Subject well being appear as the largest values, so H0 is rejected because the T-value is The statistic is far above the critical value (1.96) so it is significant at $5 \%$. The percentage of influence between variables will then be presented as follows: 
Table 17. Percentage of Influence between Variables on Variables Realization of the Food Estate Concept

\begin{tabular}{|c|c|c|c|c|c|c|c|c|}
\hline \multirow[t]{3}{*}{ No } & \multirow[t]{2}{*}{ Source } & \multirow[t]{2}{*}{$L V$} & \multirow[t]{2}{*}{ Direct Path } & Inderect & \multirow[t]{2}{*}{ Total } & Direct & Indirect & \multirow[t]{2}{*}{ Total } \\
\hline & & & & Path & & $\%$ & $\%$ & \\
\hline & (1) & (2) & (3) & (4) & $\begin{array}{l}(5) \\
3+4\end{array}$ & $\begin{array}{l}(6) \\
2 \times 3 \times 100\end{array}$ & (7) & $\begin{array}{l}(8) \\
6+7\end{array}$ \\
\hline 1 & $\begin{array}{l}\text { Understanding and } \\
\text { compliance }\end{array}$ & 0.921 & 0.352 & 0.623 & 0.975 & $32,4 \%$ & $\begin{array}{l}0 \\
.27 \%\end{array}$ & $32,67 \%$ \\
\hline 2 & Economic conditions & 0.728 & 0.146 & 0.381 & 0,527 & $10,6 \%$ & $0.62 \%$ & $11,2 \%$ \\
\hline 3 & social and cultural & 0.812 & 0.189 & 0.291 & 0,48 & $15,3 \%$ & $0.29 \%$ & $15,5 \%$ \\
\hline 4 & Policy issues & 0.809 & 0.166 & 0.176 & 0,342 & $13,4 \%$ & $0.26 \%$ & $13,6 \%$ \\
\hline 5 & $\begin{array}{l}\text { Facilities and } \\
\text { infrastructure }\end{array}$ & 0.803 & 0.133 & 0.198 & 0,331 & $10,6 \%$ & $0.14 \%$ & $10,7 \%$ \\
\hline 6 & Stakeholder Support & $\begin{array}{l}0.83 \\
7\end{array}$ & 0.192 & 0.121 & 0,313 & $16,0 \%$ & $0,12 \%$ & $16,1 \%$ \\
\hline & Total & & & & & $\mathbf{9 8 , 3 \%}$ & $1.7 \%$ & $100 \%$ \\
\hline
\end{tabular}

Based on the table, it states that the attributes of understanding and compliance have a direct and indirect effect on the realization of the food estate concept. The results of the coefficient test produce 3 main parameters that have a direct influence, namely 1) Understanding and compliance with the realization of the food estate concept shows that there is a direct effect of $32.4 \%, 2$ ) Social and cultural influence on the realization of the food estate concept shows that there is a direct effect of 15, 3\%. And 3) Stakeholder support for the realization of the food estate concept shows that there is a direct effect of $16 \%$.

The way to calculate the direct effect of understanding and adherence to the realization of the food estate concept is by multiplying the path coefficient of the understanding and adherence to the realization of the food estate concept by the latent variable, which also applies to the calculation of the path coefficient of other variables. The results of the direct effect are:

1. Direct influence Understanding and compliance with the realization of the food estate concept Direct Path (Understanding and compliance Realization of the food estate concept $x$ LV Correlation (understanding and compliance Realization of the food estate concept $)=(0.921) \times(0.352) \times 100 \%=32.4 \%$

2. The direct influence of economic conditions on the realization of the food estate concept Direct Path (Economic conditions $\square$ Realization of the food estate concept $\mathrm{x}$ LV Correlation (Economic conditions Realization of the food estate concept $)=(0.728) \mathrm{x}$ $(0.146) \times 100 \%=10.6 \%$

3. The direct influence of policy issues on the realization of the food estate concept Direct Path (Policy issues Realization of the food estate concept $x$ LV Correlation (Policy issues Realization of the food estate concept $)=(0.812) \times(0.189) \times 100 \%=15.3 \%$

4. Social and cultural direct influence on the realization of the food estate concept Direct Path (Social and cultural Realization of the food estate concept x LV Correlation (Social and cultural Realization of the food estate concept $)=(0.809) \times(0.166) \times 100 \%=13.4 \%$

5. The direct influence of facilities and infrastructure on the realization of the food estate concept Direct Path (Facilities and infrastructure Realization of the food estate concept $x$ LV Correlation (Facilities and infrastructure Realization of the food estate concept $)=$ $(0.803) \times(0.133) \times 100 \%=10.6 \%$ 
6. Direct influence Stakeholder support on the realization of the food estate concept Direct Path (Stakeholder support Realization of the food estate concept x LV Correlation $($ Stakeholder support Realization of the food estate concept $)=(0.837) \times(0.192) \times 100 \%$ $=16.0 \%$

So that from each of the direct effects of the exogenous latent variables, if together they show conformity with $\mathrm{R}$ square or in other words, it states that the variables of understanding and compliance, economic conditions, policy issues, social and culture, capabilities and stakeholder support are $(32.4 \%+10.6 \%+15.3 \%+13.4 \%+10.6 \%+$ $16.0 \%)=98.3$. Meanwhile, the indirect effect between understanding and compliance with the realization of the food estate concept is $0.27 \%$, the indirect effect between economic conditions on the realization of the food estate concept is $0.62 \%$, and the indirect effect between social and culture on the realization of the food estate concept is $0.29 \%$. , the indirect effect of policy issues on the realization of the food estate concept is $0.26 \%$. the indirect effect between facilities and infrastructure is $0.14 \%$. while the indirect effect of stakeholder support on the realization of the food estate concept is $0.12 \%$.

\section{Conclusion}

The test results found that the variable realization of the concept of food estate on farmer card ownership for the community as a result of BNI corporate cooperation in Pulang Pisau Regency was influenced by the influence of understanding and compliance (32.4\%), economic conditions (10.6\%), policy issues (15.3\%), social and cultural (13.4\%), facilities and infrastructure (13.4\%) and stakeholder support (10.6\%). Based on these findings, it can be concluded that the implementation of the farmer's card which consists of 6 measurement indicators is something that will relate to success and policy making in the realization of the food estate concept in Pulang Pisau Regency. The study has limitations on the number of samples and time as well as face-to-face limitations to obtain in-depth data due to the pandemic, but is able to answer to show acceptance and analyze factors that can affect the potential for food estate realization in Pulang Pisau Regency through the procurement of BNI farmer cards.

\section{References}

Aday, Serpil, dkk. (2020). Impacts of Covid-19 on Food Supply Chain. Food Processing Departement Canakkale, Turkey.

Ashari, dkk. (2019). Analisis Efektivitas Program Kartu Tani Di Kecamatan Banjarnegara Kabupaten Banjarnegara. Departemen administrasi publik fakultas ilmu sosial dan ilmu politik Universitas Diponegoro.

Bhwana, P. G. (2020). FAO Warns COVID-19 Pandemic Can Cause Global Food Crisis. Tempo. https://en.tempo.co/read/1392904/three-more-doctors-died-of-covid-19bringing- death-toll-to-130-idi

BNI. (2020). Implementasi Kartu Tani. Jakarta: Divisi Pengelolaan Jaringan PT Bank Negara Indonesia.

Cai, Xiaojing, dkk. (2020). Co-Movements In Commodity Markets And Implications In Diversification Benefits. Journal of Empirical Economics Vol 58 Issues 2.

Chakim, Muhammad L. (2019). Pengaruh Implementasi Kartu Tani Terhadap Efektivitas Penyaluran Pupuk Bersubsidi Di Kabupaten Kendal, Jawa Tengah. Jurnal Pangan Volume 28 No.3) 
Dianto E., et al. (2020). BNI Marketing Strategy for Credit Cards in Dealing Global Competition in State Bank Indonesia (Persero) Tbk Banda Aceh Branch Office. Budapest International Research and Critics Institute-Journal (BIRCI-Journal) Vol 3, No 2, Page: 1134-1146.

Fahmi, Devi N, dkk. (2020). Persepsi Petani Terhadap Implementasi Kartu Tani (Studi Kasusdesa Kadirejo Kecamatan Pabelan, Kabupaten Semarang). Jurnal Agrisep Vol 19 No 2

Isabella, Mesiastri P. (2020). Analisis Efektivitas Penggunaan Kartu Tani di eks Karesidenan Pati. Jurnal Ziraah Volume 45 No 2.

Komarayanti, S., et al. (2018). Business of Local Fruit and Vegetables in Jember District as a Support of Food Security, Indonesia. Budapest International Research and Critics Institute-Journal (BIRCI-Journal) Vol I, No 3, Page: 208-224

Kurniawati, Etik. (2020). Persepsi Masyarakat Terhadap Penggunaan Kartu Tani di Kabupaten Pati (Kasus di Desa Wotan dan Desa Pakem, Kecamatan Sukolilo).

Laborde, David, dkk. Covid-19 Risk To Global Food Security: Economic fallout and food supply chain disruptions require attention from policy-makers. Insight Vol 369 Issue 6503.

Masudin, Ilyas, dkk. (2020). Food Cold Chain In Indonesia During The Covid-19 Pandemic: A Current Situation And Mitigation. Jurnal Rekayasa Sistem Industri Volume 9 No 2.

Pierre, Guillaume, dkk. (2020). Agricultural Grain Markets In The Covid-19 Crisis, Insights From A Gvar Model. Department of Agricultural Sciences, University of Sassari, Italy. 